\title{
Antiproliferative effects on colon adenocarcinoma cells induced by co-administration of vitamin K1 and Lactobacillus rhamnosus GG
}

\author{
ANTONELLA ORLANDO, MICHELE LINSALATA and FRANCESCO RUSSO \\ Laboratory of Nutritional Pathophysiology, National Institute for Digestive Diseases \\ I.R.C.C.S. 'Saverio de Bellis', Castellana Grotte, I-70013 Bari, Italy
}

Received December 28, 2015; Accepted February 18, 2016

DOI: $10.3892 /$ ijo.2016.3463

\begin{abstract}
Vitamin K (VK), an essential nutrient associated with the clotting cascade, has also been demonstrated to have anticancer properties in various cancer cells including colon cancer cells. Also probiotics have gained interest as potential anticancer agents. Among them, Lactobacillus rhamnosus GG (L.GG) has been shown to inhibit cell proliferation and polyamine biosynthesis as well as to induce apoptosis in different human gastrointestinal cancer cells. Nevertheless, the exact mechanisms involved in these actions are not completely elucidated. Therefore, the aims of the present study were to evaluate in three differently graded human colon cancer cells (namely Caco-2, HT-29 and SW480) the effects of increasing VK1 concentrations, administered alone or in combination with viable L.GG, on the cell proliferation evaluated by MTT test, apoptosis investigated by $\mathrm{Bax} / \mathrm{Bcl}-2$ ratio and the percentage of the apoptotic cells, and the cell cycle evaluated by MUSE cell analyzer. Both VK1 and L.GG administered alone up to $72 \mathrm{~h}$, caused inhibition of proliferation, induction of apoptosis and the cell cycle arrest in all the tested colon cancer cells. When VK1 and L.GG were co-administered, the addition of increasing VK1 concentrations potentiated the probiotic antiproliferative effect in a dose-dependent manner, being also related to the individual features of each cell line. The effect was more evident in Caco-2 and HT-29 cells compared to the less differentiated SW480. The enhanced antiproliferative efficacy due to co-administration of L.GG and VK1 could represent a suitable option in a functional food strategy for cancer growth inhibition and chemoprevention.
\end{abstract}

Correspondence to: Dr Francesco Russo, Laboratory of Nutritional Pathophysiology, National Institute for Digestive Diseases I.R.C.C.S. 'Saverio de Bellis', via Turi 27, Castellana Grotte, I-70013 Bari, Italy E-mail: francesco.russo@irccsdebellis.it

Key words: apoptosis, cell cycle, chemoprevention, colon cancer cells, lactobacillus rhamnosus GG, probiotics, proliferation, vitamin K1

\section{Introduction}

Colorectal cancer (CRC) remains among the leading causes of cancer death in Western countries (1). Unfortunately, its management following the ordinary chemotherapy protocols is not satisfactory, and an alternative practical approach to reduce the related morbidity and mortality could be to arrest or delay the process of carcinogenesis by using chemopreventive agents (2). Chemoprevention has been defined as all the treatments, nutritional or pharmacologic, that prevent, arrest, or even regress the neoplastic growth in one or more organs (3).

Diet and nutrition are considered key factors in modulating CRC onset and progression; therefore, identifying those dietary components with putative antitumor activity and investigating their mechanisms of action may lead to significant advances in tumor prevention and inhibition. Data in literature have emphasized a protective role against CRC by different natural compounds such as flavonoids, polyphenols (resveratrol and its analogs) and probiotics (4).

Until very recently, vitamin $\mathrm{K}(\mathrm{VK})$ was not considered capable of playing a role against CRC, being just a critical factor involved in the blood coagulation. The VK family is composed by structurally similar 2-methyl-1,4-naphthoquinones, which includes phylloquinone (VK1), menaquinone (VK2) and menadione (VK3) (5). However, in recent years growing attention has been dedicated to their possible anticancer effects in relation to their ability to inhibit cancer cell growth (6).

VK1 is found in many higher plants as well as algae and in green leafy vegetables. Although the majority of the published data are related to hepatocellular carcinoma (HCC) (7), its anticancer potentiality has also been postulated on different human colon cancer cell lines. Several mechanisms of action have been proposed, including alteration of the expression of some growth related genes involved in the cell cycle arrest (8) and the induction of apoptosis by the phosphorylation of extracellular signal-regulated kinase (ERK) (9).

In addition to the above proposed VK1 mechanisms of cancer inhibition, studies by our group demonstrated the ability of VK1 to affect the biosynthesis of cellular polyamines (spermidine, spermine and putrescine), polycations 
essential for growth and DNA synthesis $(10,11)$ that have also been suggested as putative markers for neoplastic proliferation (12).

Also probiotics have progressively gained interest in the scientific community as chemopreventive agents. These bacteria are defined as 'dietary supplements, containing viable non-pathogenic microorganisms, which confer health benefits to the host' (13). Different in vitro and in vivo as well as epidemiological studies have focused on their anticancer potential, demonstrating their active role against cancer (14). Along with the most proposed mechanisms of action (e.g. alteration of the intestinal microflora metabolism, inactivation of cancerogenic compounds, improvement of the host's immune response), they have been suggested to be effective in preventing cancer initiation and progression (15) and to inhibit cell proliferation via regulation of apoptosis and cell differentiation (16).

Several strains belonging to Lactobacilli and Bifidobacteria have been shown to be effective in suppression of CRC incidence (17). In previous in vitro studies by our group, Lactobacillus rhamnosus GG (L.GG), tested as both viable and heat inactivated bacteria as well as homogenate and cytoplasm extracts, demonstrated significantly decreased cell proliferation, induced apoptosis and influenced the polyamine metabolism of a number of human gastrointestinal (GI) cancer cells $(18,19)$.

In spite of large volumes of data in literature, the exact knowledge of the mechanisms mediating the probiotic anticancer effects are still not completely obtained. Besides, investigating the effects following the co-administration of this probiotic bacteria with other synergistically acting components of natural origin such as VK1, could offer new strategies to improve their efficacy. Together with the co-administration of probiotics with 'prebiotics' (e.g resistant starch, pectin, betaglucans and xylooligosaccharides) (20) to form 'synbiotics' (21) numerous other substances such as nutrients, growth factors, proteins, polyunsaturated fatty acids (PUFAs), organic acids and bacterial metabolites have been proposed (22). Considering that VK and its analogues have been suggested as growth factors for different bacterial strains (23-25), a possible co-administration of VK1 with probiotics could improve their putative chemopreventive properties against CRC.

In light of these considerations, the aims of the present study were to evaluate the effects of increasing VK1 concentrations and viable L.GG, administered alone or in combination with VK1, on cell proliferation, apoptosis and the cell cycle, in three differently graded human colon cancer cell lines, the Caco-2, HT-29 and SW480.

\section{Materials and methods}

Cell culture conditions. Human colon adenocarcinomaderived Caco-2 cell line (well differentiated) (G1-2) (from adenocarcinoma), HT-29 cell line (moderately well differentiated) (G2) (from adenocarcinoma grade II), and SW480 cell line (low differentiated) (G3-4) (from adenocarcinoma grade III-IV) were obtained from the Interlab Cell Line Collection (Genoa, Italy). These colonic adenocarcinoma cells were used since they may represent the spectrum of cellular changes seen in precancerous lesions and the manifest tumors (26). Cells were routinely cultured in RPMI-1640, McCoy's 5A and Leibovitz L-15 medium, respectively, supplemented with $10 \%$ fetal bovine serum (FBS), $2 \mathrm{mM}$ glutamine, $100 \mathrm{U} / \mathrm{ml}$ penicillin, $100 \mu \mathrm{g} / \mathrm{ml}$ streptomycin, in a monolayer culture, and incubated at $37^{\circ} \mathrm{C}$ in a humidified atmosphere containing $5 \% \mathrm{CO}_{2}$ in air. At confluence, the grown cells were harvested by means of trypsinization and serially sub-cultured with a 1:4 split ratio. All cell culture components were purchased from Sigma-Aldrich (Milan, Italy).

Bacterial strain. As probiotic, the Lactobacillus rhamnosus ATCC 53103 (commercially named Lactobacillus GG, L.GG, obtained from the American Type Culture Collection, Manassas, VA, USA) was used. L.GG was cultured at $37^{\circ} \mathrm{C}$ for $24 \mathrm{~h}$ under anaerobic conditions in Man, Rogosa, Sharpe (MRS) broth; the incubate was centrifuged ( $300 \mathrm{x} \mathrm{g}$ for $10 \mathrm{~min}$ ) at room temperature and the precipitate was collected and washed twice with phosphate-buffered saline (PBS) at $\mathrm{pH}$ 7.4. Bacteria were then resuspended in the cell culture medium in order to give a bacterial concentration of $10^{8} \mathrm{CFU} / \mathrm{ml}$ (as determined by colony count).

Growth stimulation of L.GG by VK1. The supposed growth promoting activity of VK1 on L.GG was assayed incubating the probiotic strain $\left(10^{8} \mathrm{CFU} / \mathrm{ml}\right)$ at $37^{\circ} \mathrm{C}$ under anaerobic conditions in MRS broth supplemented with increasing VK1 concentrations (50, 100 and $200 \mu \mathrm{M})$ for 2, 4, 6, 12, 18 and $24 \mathrm{~h}$. Then, the optical density $\left(\mathrm{A}_{600}\right.$, absorbance at $\left.600 \mathrm{~nm}\right)$ was measured at each time by a spectrophotometer.

VK1 and L.GG treatment. Caco-2, HT-29 and SW480 cells (25th-30th passage) were seeded at a density of $2 \times 10^{5}$ cells $/ 5 \mathrm{ml}$ of supplemented RPMI-1640, McCoy's 5A and Leibovitz L-15 medium, respectively, in 60-mm tissue culture dishes (Corning Costar Co., Milan, Italy). After $24 \mathrm{~h}$, to allow for attachment, each medium was removed and supplemented medium containing increasing concentrations of VK1 $(10,50,100$ and $200 \mu \mathrm{M}$ ) was added to cells for 24,48 and $72 \mathrm{~h}$. A concomitant set of experiments was conducted by administering to the three cell lines for the same time period, viable L.GG $\left(10^{8}\right.$ $\mathrm{CFU} / \mathrm{ml}$ ) alone or in combination with increasing concentrations of VK1. Triplicate cultures were set up for each treatment and for the control, and each experiment was repeated 3 times. Cytotoxicity, determined using the Trypan blue exclusion test, was always $<10 \%$.

Assessment of cell proliferation. After Caco-2, HT-29 and SW480 cells had been cultured for 24, 48 and $72 \mathrm{~h}$ with increasing concentrations of VK1, viable L.GG and L.GG in combination with VK1, the proliferative response was measured by colorimetric 3-(4,5di-methylthiazol-2-yl)2,5-diphenyltetrazolium bromide (MTT) test. To determine cell growth by colorimetric test, MTT stock solution $(5 \mathrm{mg} / \mathrm{ml}$ in medium) was added to each dish at a volume of one tenth the original culture volume and incubated for $2 \mathrm{~h}$ at $37^{\circ} \mathrm{C}$ in humidified $\mathrm{CO}_{2}$. At the end of the incubation period, the medium was removed and the blue formazan crystals were solubilized with acidic isopropanol $(0.1 \mathrm{~N} \mathrm{HCl}$ absolute isopropanol). MTT conversion to formazan by metabolically viable cells was monitored by spectrophotometer at an optical density of $570 \mathrm{~nm}$. 
Apoptosis. The apoptosis was measured by the quantitative PCR (qPCR) method with SYBR-Green I for the evaluation of Bax and Bcl-2 mRNA expression (reported as Bax/Bcl-2 ratio), and the Muse Cell Analyzer for the quantitative analysis of live, early and late apoptotic, as well as dead cells.

As concerns qPCR, the cells were washed twice in PBS and then trypsinized and centrifuged at $280 \mathrm{x} \mathrm{g}$. The cell pellets were re-suspended in $0.3 \mathrm{ml}$ of pure distilled water and used for RNA extraction. Total cell RNA was extracted using TRI reagent (Molecular Research Center, Cincinnati, OH, USA), following the manufacturer's instructions. Approximately $2 \mu \mathrm{g}$ total cell RNA, extracted from both the control and treated cells, was used for cDNA synthesis. Reverse transcription (RT) was carried out in $20 \mu \mathrm{l}$ of the final volume at $41^{\circ} \mathrm{C}$ for $60 \mathrm{~min}$, using $30 \mathrm{pmol}$ antisense primers for analyses of Bax, $\mathrm{Bcl}-2$ and $\beta$-actin gene (27). The $\beta$-actin gene was utilized as an internal control and was chosen as a reference gene because it is a housekeeping gene. Real-time PCRs were performed in $25 \mu \mathrm{l}$ of final volume containing $2 \mu \mathrm{l}$ of cDNA, Master Mix with SYBR-Green (iQ SYBR Green Supermix; Bio-Rad Laboratories, Milan, Italy) and sense and antisense primers for Bax, Bcl-2 and $\beta$-actin gene. Real-time PCRs were carried out in a CFX96 Real-Time PCR Detection System (Bio-Rad Laboratories) using the following protocol: 45 cycles at $95^{\circ} \mathrm{C}$ for $3 \mathrm{~min}, 95^{\circ} \mathrm{C}$ for $10 \mathrm{sec}, 55^{\circ} \mathrm{C}$ for $30 \mathrm{sec}$ followed by a melting curve step at $65-95^{\circ} \mathrm{C}$ with a heating rate of $0.5^{\circ} \mathrm{C}$ per cycle for 80 cycles. The PCR products were quantified by external calibration curves, one for each tested gene, obtained with serial dilutions of known copy number of molecules $\left(10^{2}-10^{7}\right.$ molecules). All expression data were normalized by dividing the target amount by the amount of $\beta$-actin used as internal control for each sample. The specificity of the PCR product was confirmed by gel electrophoresis.

Additionally, the apoptotic process was evaluated by the Muse Cell Analyzer using the Muse Annexin V/Dead Cell kit (Merck-Millipore, Darmstadt, Germany) following the supplier's instructions. The assay utilizes Annexin V to detect phosphatidylserine (PS) on the external membrane of apoptotic cells. A dead cell marker (7-AAD) is also used as an indicator of cell membrane structural integrity. Three populations of cells can be distinguished: the viable cells [Annexin $\mathrm{V}(-)$ and 7-AAD(-)], the early apoptotic cells [Annexin $\mathrm{V}(+)$ and 7-AAD $(-)$ ], the late apoptotic and dead cells [Annexin $\mathrm{V}(+)$ and 7-AAD $(+)]$.

Cell cycle analysis. Quantitative measurement of the percentage of cells in the G0/G1, S and G2/M phases of the cell cycle was performed by using the Muse Cell Cycle kit (Merck-Millipore) following the supplier's instructions. The assay uses a premixed reagent which includes the nuclear DNA intercalating stain propidium iodide (PI) and RNAse A in a proprietary formulation. PI discriminates cells at different stages of the cell cycle based on differential DNA content in the presence of RNAse to increase the specificity of DNA staining. The proportion of nuclei in each phase of the cell cycle was then determined using the Muse Cell Cycle Software Module, which displayed the data in two plots: i) DNA content index and cell size index dot plot; ii) DNA content index histogram with markers available to analyze the cell populations in each phase of the cycle.

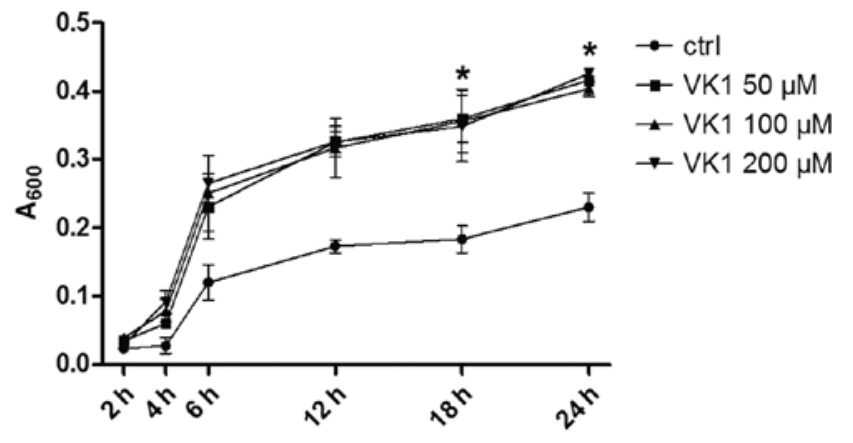

Figure 1. Growth promoting activity of vitamin K1 (VK1) on L.GG. Effects of increasing VK1 concentrations $(50,100$ and $200 \mu \mathrm{M})$ on the growth of L.GG after 2, 4, 6, 12, 18 and $24 \mathrm{~h}$ of treatment. All data are expressed as $\mathrm{A}_{600}$ and represent the result of three different experiments (mean \pm SEM). For each VK1 concentration, data were analyzed by Friedman repeated measures analysis of variance on ranks. ${ }^{*} \mathrm{P}<0.05$ compared to control for all the VK1 concentrations.

Statistical analysis. Due to the non-normal distribution of the data, non-parametric tests were performed. Data were analyzed by Kruskal-Wallis analysis of variance and Dunn's multiple comparison test and Friedman repeated measures analysis of variance on ranks where appropriated. All data are expressed as mean and SEM. Differences were considered significant at $\mathrm{P}<0.05$. A specific software package was used for the statistical analysis (Stata Statistical Software: Release 9; StataCorp LP, College Station, TX, USA).

\section{Results}

Effects of VK1 on the growth of L.GG. To explore whether VK1 could promote the growth of L.GG, increasing VK1 concentrations were administered to the probiotic up to $24 \mathrm{~h}$. As reported in Fig. 1, L.GG growth was stimulated by VK1 as demonstrated by the massive increase of $A_{600}$. The effect started precociously after $4 \mathrm{~h}$, reaching the statistical significance at $18 \mathrm{~h}$ of incubation with all the VK1 concentrations compared to control $(\mathrm{P}<0.05)$.

Effects of VKI and L.GG treatment on cell proliferation. Exposure of Caco-2, HT-29 and SW480 cell lines to increasing VK1 concentrations up to $72 \mathrm{~h}$ caused clearly evident antiproliferative effect as demonstrated by the conversion of the MTT tetrazolium salt (Fig. 2).

In Caco-2 cells, VK1 at the highest concentrations (100 and $200 \mu \mathrm{M})$ inhibited the proliferation significantly $(\mathrm{P}<0.05)$. The effect was rapid, starting after $24 \mathrm{~h}$ of administration and persisted up to $72 \mathrm{~h}$, causing at this exposure time a marked reduction of viability (by 43.4 and $44.3 \%$ at 100 and $200 \mu \mathrm{M}$, respectively) (Fig. 2A-C). With L.GG administered alone to Caco-2 cells, a significant $(\mathrm{P}<0.05)$ inhibition of proliferation was observed after 48 and $72 \mathrm{~h}$ of treatment (Fig. 2B and $\mathrm{C}$ ). The percentage of viability decreased by 44.8 and $71.3 \%$, respectively. When L.GG was co-administered with increasing VK1 concentrations, the antiproliferative effect was significantly $(\mathrm{P}<0.01)$ enhanced in a dose-dependent manner starting at $48 \mathrm{~h}$ (Fig. 2B). L.GG in combination with 50, 100 and $200 \mu \mathrm{M}$ VK1 concentrations caused a reduction compared to control cells by $55,85,1$ and $85.5 \%$, respectively. After $72 \mathrm{~h}$ 

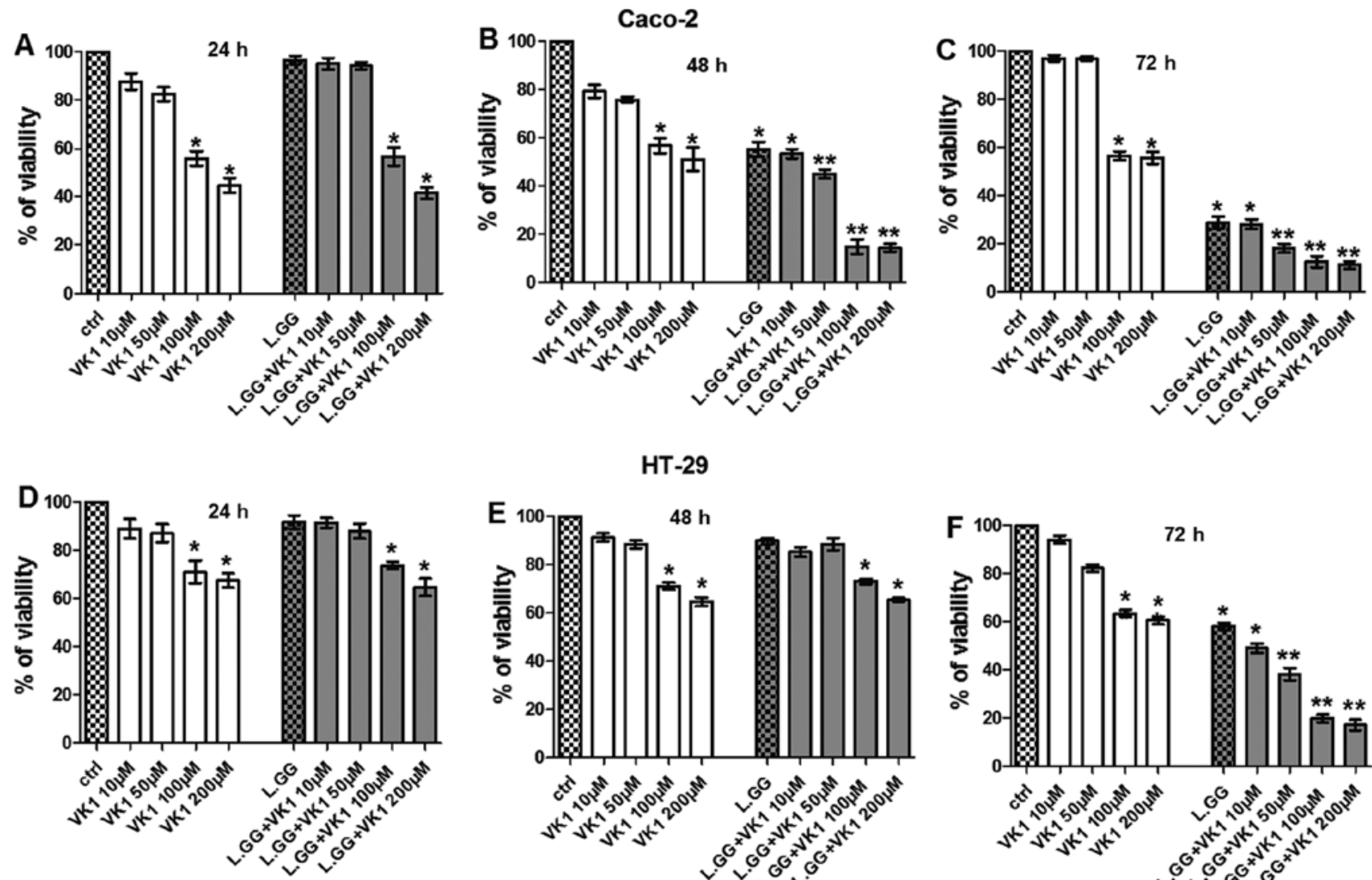

HT-29
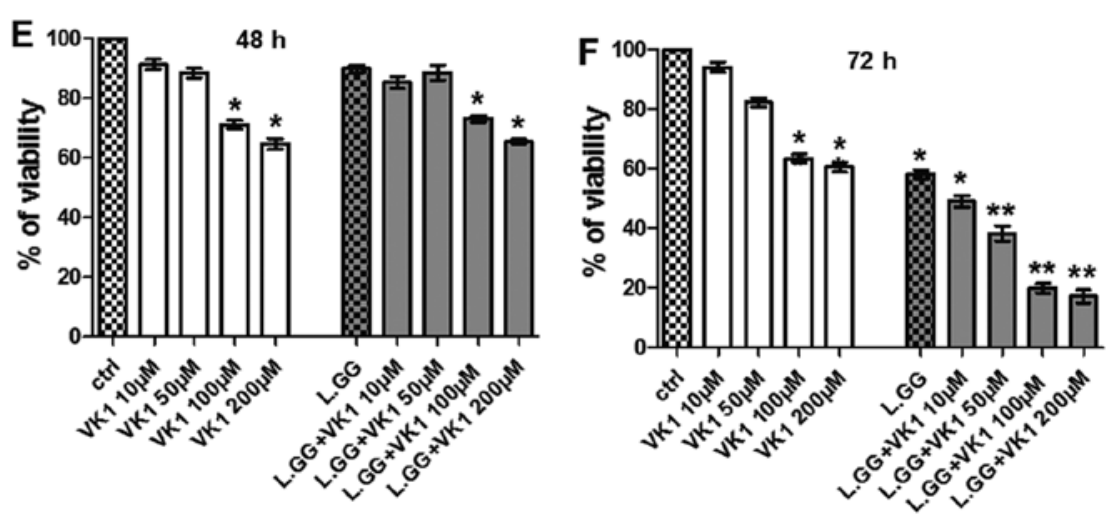

SW480
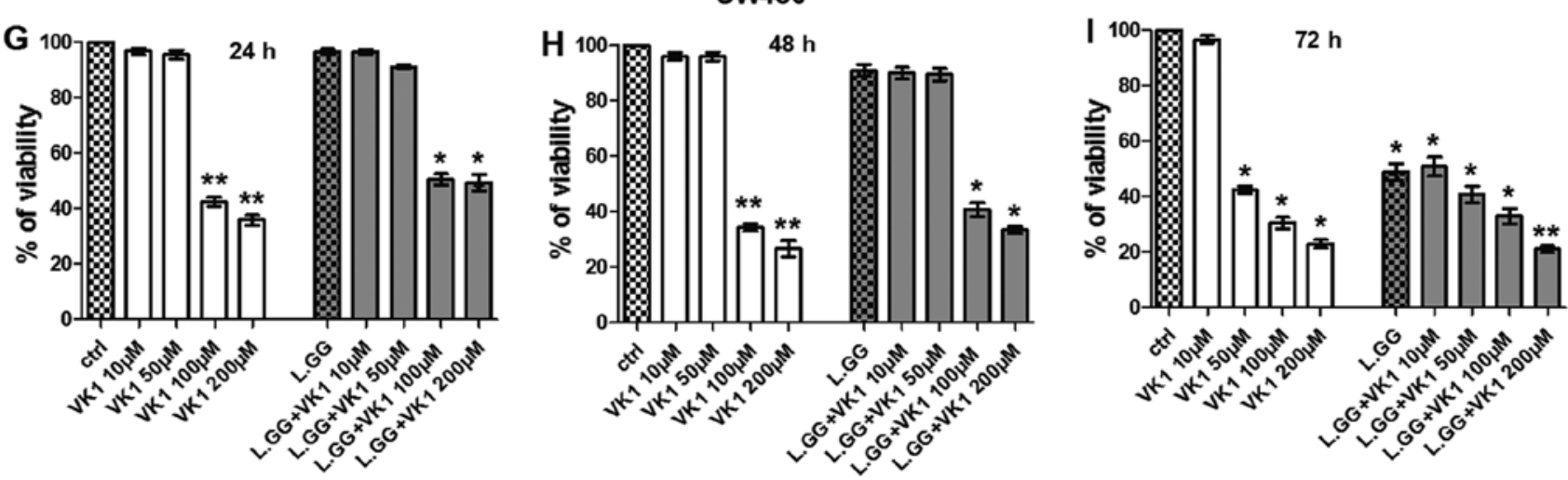

Figure 2. Proliferative response of Caco-2, HT-29 and SW480 cell lines to vitamin K1 (VK1) and L.GG treatment. Effects of increasing VK1 concentrations $(10,50,100$ and $200 \mu \mathrm{M})$ alone or in combination with viable L.GG $\left(10^{8} \mathrm{CFU} / \mathrm{ml}\right)$ on the conversion of MTT tetrazolium salt in Caco-2 (A-C), HT-29 (D-F) and SW480 cell lines (G-I) after 24,48 and $72 \mathrm{~h}$ of treatment. The data represent the result of three different experiments (mean \pm SEM). For each time of treatment, data were analyzed by Kruskal-Wallis analysis of variance and Dunn's multiple comparison test. ${ }^{*} \mathrm{P}<0.05,{ }^{* *} \mathrm{P}<0.01$ compared to control cells.

of exposure at the same concentrations, the antiproliferative effect was still present with a significant reduction $(\mathrm{P}<0.01)$ by $81.7,87.4$ and $88.8 \%$ compared to control cells, respectively (Fig. 2C).

Also in HT-29 cell line, VK1 administered alone at the highest concentrations led to a significant $(\mathrm{P}<0.05)$ lessening of the percentage of viability compared to control cells at all the tested times, reaching at $72 \mathrm{~h}$ a 36.5 and $39.3 \%$ reduction of viability for 100 and $200 \mu \mathrm{M}$, respectively (Fig. 2D-F). On the contrary, the L.GG treatment in HT-29 was less effective in inhibiting proliferation than that in Caco-2, since it caused a significant $(\mathrm{P}<0.05) 41.9 \%$ reduction of the percentage of viability compared to control cells only after $72 \mathrm{~h}$ of treatment
(Fig. 2F). However, also in this cell line, the co-administration of L.GG with increasing VK1 concentrations led to a significant $(\mathrm{P}<0.01)$ enhancement of the antiproliferative effect in a similar manner to that in Caco-2 cells (Fig. 2D-F). The antiproliferative effect was evident after $72 \mathrm{~h}$ of exposure to L.GG co-administered with 50,100 and $200 \mu \mathrm{M}$ VK1 concentrations with significant $(\mathrm{P}<0.01)$ reductions compared to control cells (61.6, 80.1 and $82.8 \%$, respectively) (Fig. 2F).

Finally, in SW480 cells 24 and $48 \mathrm{~h}$ of exposure to the highest VK1 concentrations were more effective than that in the other two cell lines in reducing the percentage of viability compared to control cells (Fig. $2 \mathrm{G}$ and H). After $24 \mathrm{~h}$ of exposure, 100 and $200 \mu \mathrm{M}$ caused a significant $(\mathrm{P}<0.01)$ reduction 

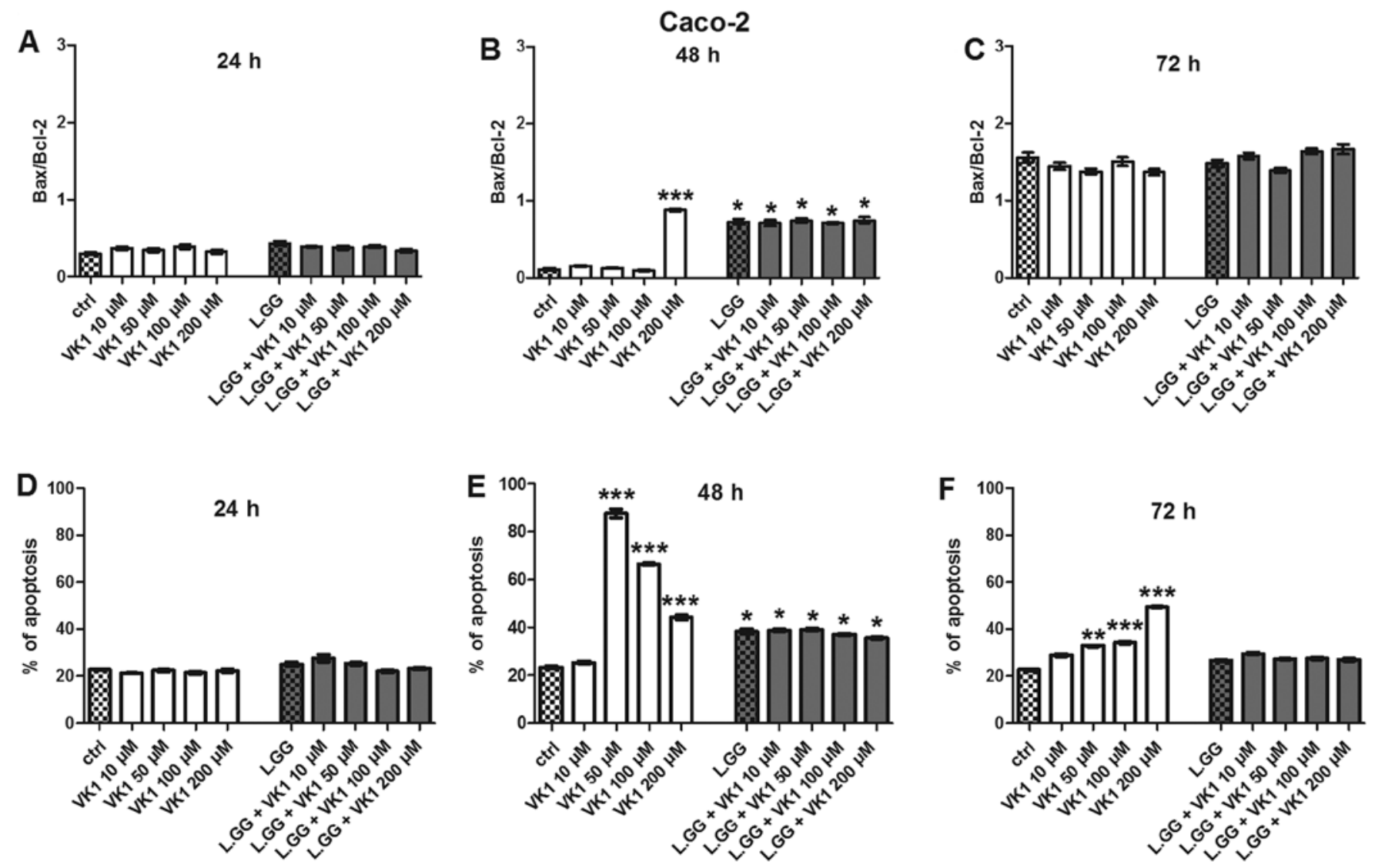

Figure 3. Apoptotic response of Caco-2 cell line to vitamin K1 (VK1) and L.GG treatment. Effects of increasing VK1 concentrations (10, 50, 100 and $200 \mu \mathrm{M})$ alone or in combination with viable L.GG $\left(10^{8} \mathrm{CFU} / \mathrm{ml}\right)$ on the Bax/Bcl-2 ratio (A-C) and the percentage of the apoptotic cells (D-F) in Caco-2 cell line after 24,48 and $72 \mathrm{~h}$ of treatment. The data represent the result of three different experiments (mean \pm SEM). For each time of treatment, data were analyzed by Kruskal-Wallis analysis of variance and Dunn's multiple comparison test. ${ }^{*} \mathrm{P}<0.05,{ }^{* * *} \mathrm{P}<0.01,{ }^{* * * *} \mathrm{P}<0.001$ compared to control cells.

of viability (57.6 and $64.1 \%$, respectively) (Fig. $2 \mathrm{G}$ ). After $48 \mathrm{~h}$, the percentages of reduction of viability with the same concentrations were marked and significant $(\mathrm{P}<0.01)$, being 65.8 and $73.4 \%$, respectively (Fig. $2 \mathrm{H}$ ). After $72 \mathrm{~h}$, along with the highest 100 and $200 \mu \mathrm{M}$, also $50 \mu \mathrm{M}$ VK1 concentration caused a significant $(\mathrm{P}<0.05) 57.6 \%$ reduction of viability compared to control cells (Fig. 2I). The effects of treatment with L.GG alone or co-administered with increasing VK1 concentrations were similar to those observed in HT-29 cell line (Fig. 2G-I). In detail, the exposure of SW480 to L.GG alone caused a significant $(\mathrm{P}<0.05) 51.0 \%$ reduction of viability compared to control cells only after $72 \mathrm{~h}$ of treatment (Fig. 2I). The co-administration of L.GG with VK1 potentiated significantly $(\mathrm{P}<0.05)$ the antiproliferative effect starting at $72 \mathrm{~h}$ with the highest VK1 concentrations (Fig. 2I). The antiproliferative effect was evident after $72 \mathrm{~h}$ of exposure with a significant $(\mathrm{P}<0.05)$ reduction by $59.2,67.1$ and $79.0 \%$ compared to control cells when L.GG was co-administered with 50, 100 and $200 \mu \mathrm{M}$ VK1 concentrations, respectively (Fig. 2I).

Effects of VKI and L.GG treatment on apoptosis. Bax/Bcl-2 ratio and the percentage of the apoptotic cells were assessed in order to verify whether VK1 and L.GG treatment inhibited cell proliferation by inducing apoptosis.

In Caco-2 cells, $48 \mathrm{~h}$ of exposure to the highest VK1 concentration $(200 \mu \mathrm{M})$ induced an evident and significant
$(\mathrm{P}<0.001)$ 8-fold increase in the $\mathrm{Bax} / \mathrm{Bcl}-2$ ratio compared to control cells (Fig. 3B). Moreover, lower VK1 concentrations (starting from $50 \mu \mathrm{M}$ ) resulted effective in significantly $(\mathrm{P}<0.001)$ increasing the percentage of apoptotic cells (by $275.7 \%$ ) compared to control cells (Fig. 3E). This effect was significant also at $72 \mathrm{~h}$ starting with the same concentration, although to a lesser extent (45.3\% increase) (Fig. 3F). Exposure of Caco-2 cells to L.GG alone for 48, but not 24 and $72 \mathrm{~h}$, caused also a proapoptotic effect as demonstrated by the significant $(\mathrm{P}<0.05) 7$-fold increase in the $\mathrm{Bax} / \mathrm{Bcl}-2$ ratio (Fig. 3B) and 64.5\% increase of apoptotic cells (Fig. 3E) compared to control cells. The co-administration of the probiotic with all the VK1 concentrations at $48 \mathrm{~h}$ exerted the same significant pro-apoptotic effects as L.GG alone (Fig. 3B and E).

In HT-29 cell line, $48 \mathrm{~h}$ of exposure to VK1 concentrations $\geq 100 \mu \mathrm{M}$ caused a significant $(\mathrm{P}<0.01) 6$-fold increase in the Bax/Bcl-2 ratio (Fig. 4B) and $96.3 \%$ increase of the apoptotic cells (Fig. 4E) compared to control cells. As observed in Caco-2 cells, the other times of exposure to increasing VK1 concentrations did not affect apoptosis. Twenty-four hours of exposure to L.GG alone already caused a precocious and significant $(\mathrm{P}<0.05) 7$-fold increase in the $\mathrm{Bax} / \mathrm{Bcl}-2$ ratio (Fig. 4A). After $48 \mathrm{~h}$ of treatment, a significant $(\mathrm{P}<0.01) 69.1 \%$ increase in the percentage of the apoptotic cells compared to the control cells (Fig. 4E) occurred. The co-administration of the probiotic strain with all the VK1 concentrations exerted 

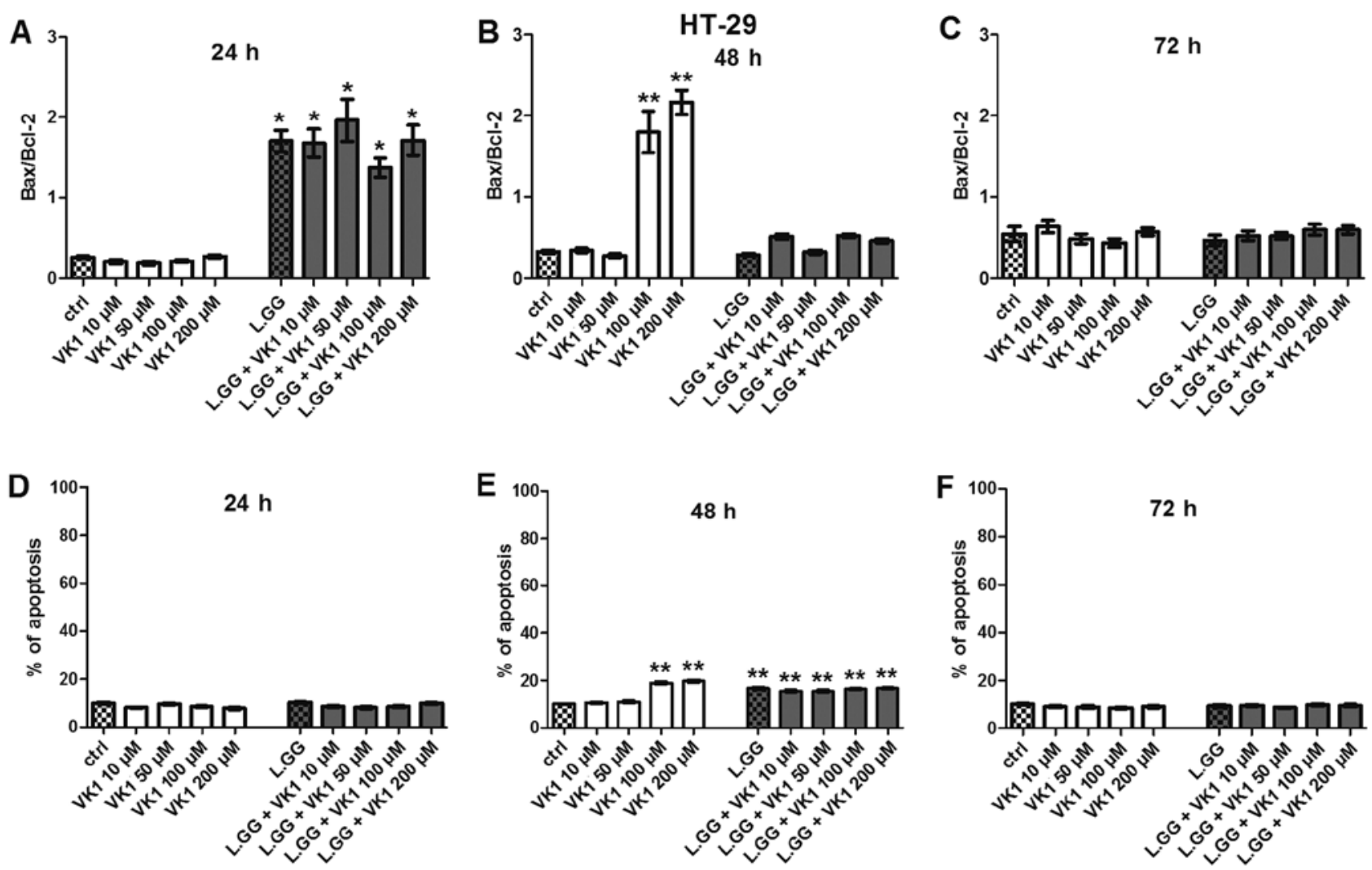

Figure 4. Apoptotic response of HT-29 cell line to vitamin K1 (VK1) and L.GG treatment. Effects of increasing VK1 concentrations $(10,50,100$ and $200 \mu \mathrm{M})$ alone or in combination with viable L.GG $\left(10^{8} \mathrm{CFU} / \mathrm{ml}\right)$ on the Bax/Bcl-2 ratio (A-C) and the percentage of the apoptotic cells (D-F) in HT-29 cell line after 24,48 and $72 \mathrm{~h}$ of treatment. The data represent the result of three different experiments (mean \pm SEM). For each time of treatment, data were analyzed by Kruskal-Wallis analysis of variance and Dunn's multiple comparison test. ${ }^{*} \mathrm{P}<0.05,{ }^{* *} \mathrm{P}<0.01$ compared to control cells.
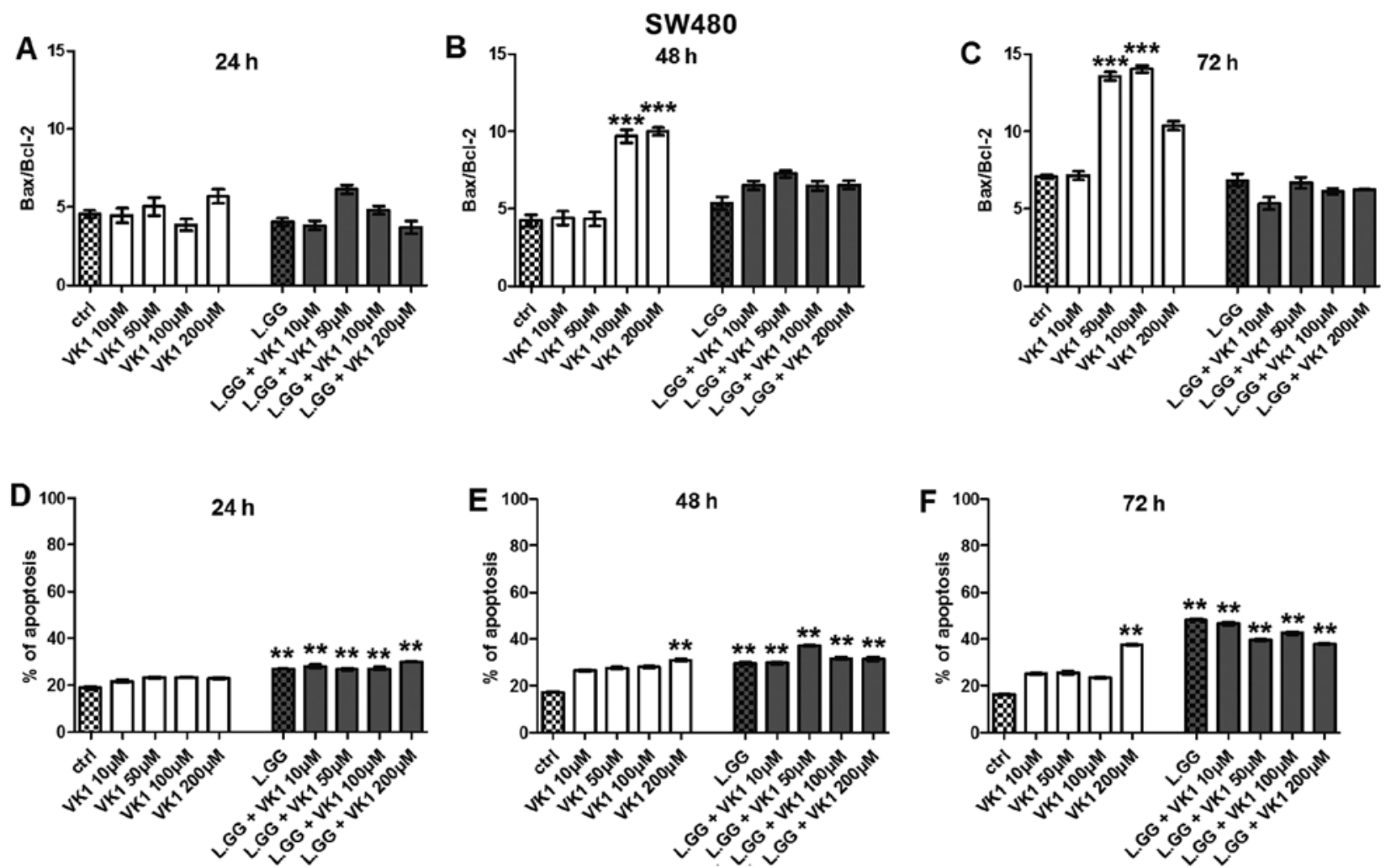

Figure 5. Apoptotic response of SW480 cell line to vitamin K1 (VK1) and L.GG treatment. Effects of increasing VK1 concentrations $(10,50,100$ and $200 \mu \mathrm{M})$ alone or in combination with viable L.GG $\left(10^{8} \mathrm{CFU} / \mathrm{ml}\right)$ on the Bax/Bcl-2 ratio (A-C) and the percentage of the apoptotic cells (D-F) in SW480 cell line after 24,48 and $72 \mathrm{~h}$ of treatment. The data represent the result of three different experiments (mean \pm SEM). For each time of treatment, data were analyzed by Kruskal-Wallis analysis of variance and Dunn's multiple comparison test. ${ }^{* * *} \mathrm{P}<0.01,{ }^{* * * *} \mathrm{P}<0.001$ compared to control cells. 

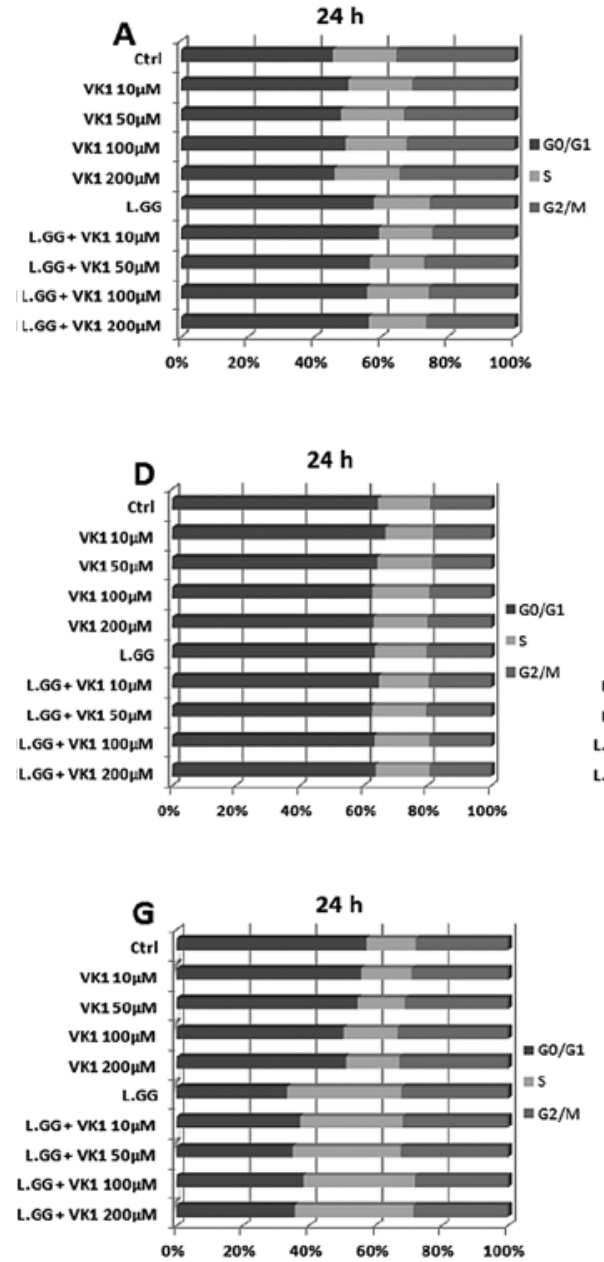
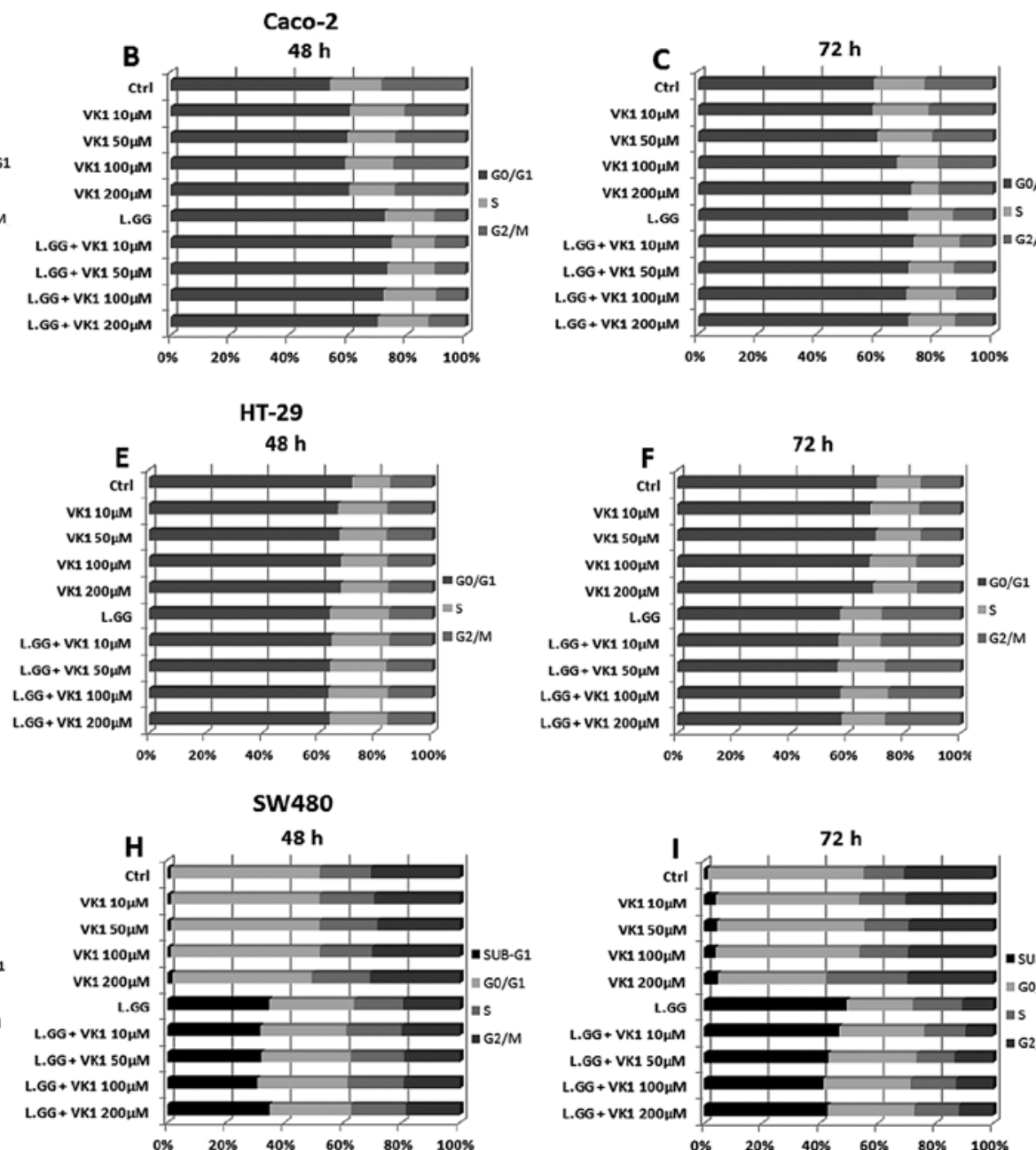
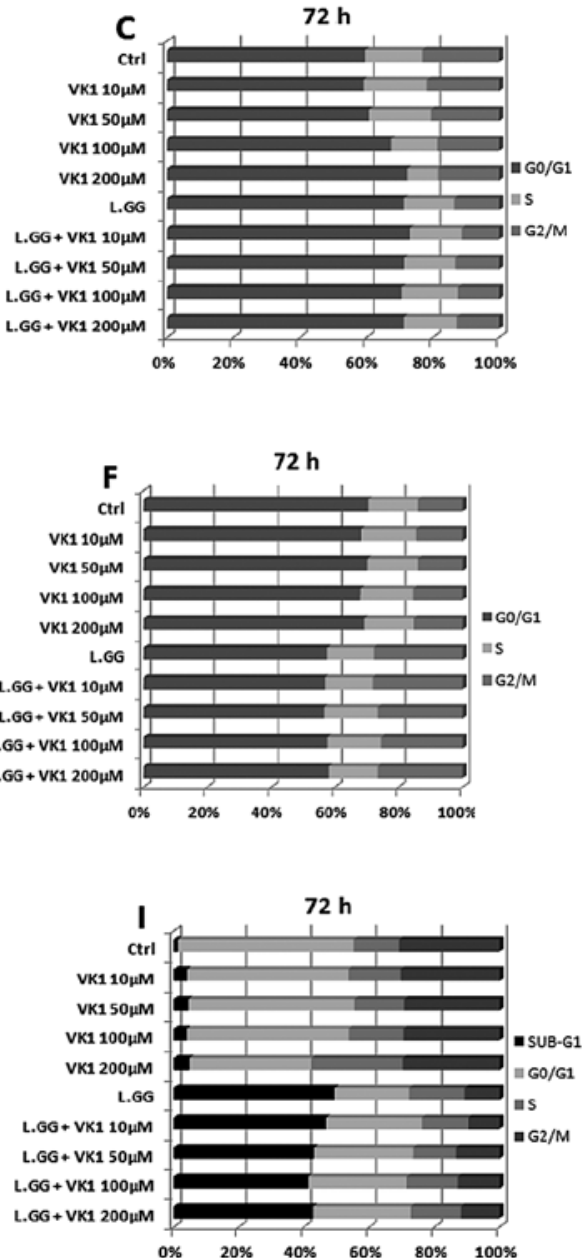

Figure 6. Effects of vitamin K1 (VK1) and L.GG treatment on cell cycle. Effects of increasing VK1 concentrations (10, 50, 100 and $200 \mu \mathrm{M})$ alone or in combination with viable L.GG $\left(10^{8} \mathrm{CFU} / \mathrm{ml}\right)$ on the distribution of the cell cycle phases in Caco-2 (A-C), HT-29 (D-F) and SW480 cell lines (G-I) after 24, 48 and $72 \mathrm{~h}$ of treatment. The data represent the result of three different experiments (mean \pm SEM). For each time of treatment, data were analyzed by KruskalWallis analysis of variance and Dunn's multiple comparison test.

the same significant pro-apoptotic effects as L.GG alone (Fig. 4A and E).

Finally, in SW480 cells, $48 \mathrm{~h}$ of exposure to VK1 concentrations $\geq 100 \mu \mathrm{M}$ caused a significant $(\mathrm{P}<0.001) 2$-fold increase in the $\mathrm{Bax} / \mathrm{Bcl}-2$ ratio compared to control cells (Fig. 5B). After $72 \mathrm{~h}$ of treatment, VK1 significantly $(\mathrm{P}<0.001)$ enhanced the ratio with a 2 -fold increase, also when administered at lower concentrations (50 and $100 \mu \mathrm{M})$ (Fig. 5C). Besides, after 48 and up to $72 \mathrm{~h}$ of exposure, the highest VK1 concentration $(200 \mu \mathrm{M})$ caused a significant $(\mathrm{P}<0.01) 79.0$ and $130.0 \%$ increase of the apoptotic cells compared to control cells, respectively (Fig. 5E and F). Notably, in this cell line the administration of L.GG alone did not exert significant effects on the $\mathrm{Bax} / \mathrm{Bcl}-2$ ratio, while it induced a significant increase $(\mathrm{P}<0.01)$ of the percentages of the apoptotic cells at all the tested times (by $43 \%$ at $24 \mathrm{~h}$, by $70.7 \%$ at $48 \mathrm{~h}$ and by $195.7 \%$ at $72 \mathrm{~h}$ ) (Fig. 5D-F). The co-administration of the probiotic with all the VK1 concentrations caused the same significant pro-apoptotic effects as L.GG alone (Fig. 5D-F).

Effects of VK1 and L.GG treatment on cell cycle. To explore whether the effects exerted by VK1 and probiotic bacteria on growth of the three cell lines involved also the cell cycle arrest, the distribution of cell cycle phases was determined.

VK1 treatment affected the cell cycle in Caco-2 cells only when the highest concentration $(200 \mu \mathrm{M})$ was administered for $72 \mathrm{~h}$ (Fig. 6C). Under these conditions, a significant $(\mathrm{P}<0.05)$ accumulation of most of the Caco-2 cells in the G0/G1 phase, accompanied by a decline of the $\mathrm{S}$ phase cells, was observed. Compared with control cells, the G0/G1 cell population increased by $22.3 \%$, while the $\mathrm{S}$ phase cells decreased by $46.9 \%$. The exposure of Caco- 2 cells to L.GG alone induced a precocious $(24 \mathrm{~h})$ and significant $(\mathrm{P}<0.01)$ cell cycle arrest of cells in the G0/G1 phase (26.6\% increase) with a significant $(\mathrm{P}<0.01) 28.5 \%$ reduction of the $\mathrm{G} 2 / \mathrm{M}$ phase cells (Fig. 6A). This effect persisted up to $72 \mathrm{~h}$ (Fig. 6B and C). The co-administration of L.GG with all the VK1 concentrations caused the same significant effects exerted by the probiotic alone (Fig. 6A-C).

In HT-29 cell line, VK1 treatment did not induce significant modifications in the cell cycle phase distribution (Fig. 6D-F). On the contrary, L.GG affected cell cycle also in this cell line. After $48 \mathrm{~h}$ of treatment the probiotic strain induced a cell cycle arrest with a significant $(\mathrm{P}<0.01) 53.7 \%$ increase of the 
S phase cells and a significant $(\mathrm{P}<0.01) 13.1 \%$ decrease of the G0/G1 phase cells compared to control cells (Fig. 6E). After $72 \mathrm{~h}, \mathrm{~L}$.GG caused a shift of the cell cycle arrest from the $\mathrm{S}$ phase to the G2/M phase (Fig. 6F). Compared to control cells, the $\mathrm{G} 2 / \mathrm{M}$ cell population significantly $(\mathrm{P}<0.01)$ increased by $98.3 \%$, while the $\mathrm{G} 0 / \mathrm{G} 1$ phase cells significantly $(\mathrm{P}<0.01)$ decreased by $18.1 \%$. These effects persisted significantly also when L.GG was co-administered with all the VK1 concentrations (Fig. 6D-F).

In a manner similar to that observed in Caco- 2 cells, the VK1 administration in SW480 cells caused the cell cycle arrest at the $S$ phase only at late stages of exposure $(72 \mathrm{~h})$ and the highest $200 \mu \mathrm{M}$ concentration (Fig. 6I). The percentage of the $\mathrm{S}$ phase cell population significantly $(\mathrm{P}<0.01)$ increased by $100 \%$, while the percentage of G0/G1 phase cells significantly $(\mathrm{P}<0.05)$ decreased by $31.0 \%$ compared to control cells. The exposure of SW480 cells to L.GG alone caused the cell cycle arrest at the $\mathrm{S}$ phase after $24 \mathrm{~h}$ of treatment (Fig. 6G). Compared to control cells, the $\mathrm{S}$ phase cell population significantly $(\mathrm{P}<0.01)$ increased by $131.3 \%$, while the $\mathrm{G} 0 / \mathrm{G} 1$ phase cells significantly $(\mathrm{P}<0.01)$ decreased by $41.8 \%$. Interestingly, after 48 and up to $72 \mathrm{~h}$, the same treatment led to a shift of the cell cycle arrest towards the G0/G1 phase as highlighted by the significant $(\mathrm{P}<0.001)$ and dramatic increase of the sub-G1 phase cells (31-fold after 48 and 41 -fold after $72 \mathrm{~h}$ ), indicative of an enhancement of apoptosis followed by a progressive decline of the G2/M phase cells (Fig. $6 \mathrm{H}$ and I). In fact, after $48 \mathrm{~h}$ the $\mathrm{G} 0 / \mathrm{G} 1$ and the $\mathrm{G} 2 / \mathrm{M}$ phase cells significantly $(\mathrm{P}<0.01)$ decreased by 45.5 and $38.9 \%$, respectively. After $72 \mathrm{~h}$ of exposure, the G0/G1 and the $\mathrm{G} 2 / \mathrm{M}$ phase cells significantly $(\mathrm{P}<0.01)$ decreased by 57.5 and $64.6 \%$, respectively. As for the other two cell-lines, the co-administration of L.GG with all the VK1 concentrations exerted the same significant effects on cell cycle as that by probiotic alone (Fig. 6G-I).

\section{Discussion}

CRC is among the leading causes of cancer related deaths all over the world (28). Both genetic and lifestyle factors (e.g. obesity, physical inactivity, diet, smoking and alcohol consumption) may contribute to cancer development and prognosis $(29,30)$. Considering that genetic factors are not modifiable, much attention has been paid to the importance of dietary interventions and the use of natural bioactive supplements for decreasing the risks of neoplastic transformation of colorectal mucosa.

Probiotics have gained much interest for their promising ability to decrease cancer risk $(14,31)$. These bacteria have been proven to be effective in reducing cancer cell viability and tumor size as well as in therapeutically inhibiting colon cancer development $(14,32)$. Among the plethora of available probiotics, L.GG, a legally approved human lactobacillus strain, has been examined for its positive effects (33-35) and it has been shown to inhibit the cell proliferation and polyamine biosynthesis together with the induction of apoptosis in different human GI cancer cell lines $(18,19,36)$.

In order to enhance the probiotic anticancer efficacy, the combination with other synergistically acting components of natural origin has been considered (20) and, in addition to synbiotics (21) the research has also investigated the possible co-administration of probiotics with other substances such as fructo-oligosaccharides, maltodextrins or PUFAs. All these molecules have been shown to enhance the effectiveness of probiotic bacteria by increasing their persistence in the GI tract and inhibiting the growth of pathogens (22).

VK, an essential nutrient associated with the clotting cascade, has also been demonstrated to have anticancer properties in a variety of cancer cell lines including colon cancer cells $(7,9-11,37)$. Many hypotheses have been formulated to explain its ability to inhibit the cell proliferation, including an active induction of the cell cycle arrest, the effects on differentiation and apoptosis with the involvement of the MAPK pathway $(7,8)$ and the control on a class of molecules affecting cell growth such as polyamines $(10,11)$.

In the present study, before co-administering VK1 and L.GG, their effects on colon cancer cells were checked separately. As already reported (10), the highest VK1 concentrations $(100$ and $200 \mu \mathrm{M})$ administered up to $72 \mathrm{~h}$ had a significant antiproliferative and proapoptotic effect in all the tested cells. On the contrary, VK1 administration induced the cell cycle arrest only in two cancer cell lines (Caco-2 and SW480) and required a prolonged time of treatment $(72 \mathrm{~h})$.

As for L.GG, the administration of this probiotic alone caused the inhibition of proliferation and induction of apoptosis in all the tested colon cancer cells. Although its effect was evident in all the three cell lines, the inhibition of cell proliferation and the induction of apoptosis appeared to be related to the cell characteristics. Actually, after $48 \mathrm{~h}$ of exposure L.GG significantly inhibited proliferation in Caco-2 cells, whereas it was necessary to extend the time of administration up to $72 \mathrm{~h}$ for the other two less differentiated cell lines (HT-29 and SW480) producing at any rate a less noticeable effect than that in Caco-2 cells. When VK1 and L.GG were co-administered, the addition of increasing VK1 concentrations potentiated the probiotic antiproliferative effect. The enhancement of L.GG efficacy with VK1 was evident also with the lowest VK1 concentrations and it appeared to be VK1 dose-dependent. Interestingly, also in the case of co-administration the effect was cell specific with a more pronounced susceptibility by Caco-2 and HT-29 cells compared to the less differentiated SW480 cells. Besides, in Caco-2 cells, L.GG administration caused an induction of apoptosis only after $48 \mathrm{~h}$ of treatment. On the contrary, in the other two cell lines the effect was precocious starting after $24 \mathrm{~h}$ and persisting up to $72 \mathrm{~h}$ in the case of SW480 cells. When L.GG was co-administered with all the VK1 concentrations the effect was significantly similar to that exerted by the probiotic alone.

With regard to cell-cycle arrest, L.GG affected the cell cycle in all the tested cells with a different distribution of the cell cycle phases depending on the considered cell line. Importantly, the co-administration of VK1 with L.GG did not potentiate the net effect on the cell cycle in any of the three cell lines since the induced arrest was the same as with L.GG alone, thus demonstrating not to be VK1-dependent. Present results are in line with the notion that different probiotic strains per se or in combination with prebiotics are able to affect the cell cycle arrest (38), but further experiments are needed to further investigate the numerous growth related genes (cyclins, CDKs) implicated in this process in relation also to the actual role played by VK1 in cell cycle. Also in the 
case of cell cycle, the special features of the cell strains used are fundamental for understanding the real VK1 effects. In this regard, Tokita et al (39) demonstrated that another component of VK family, VK2, exhibits an antitumor effect on gastric cancer cell lines affecting both cell cycle and apoptosis, but this effect was different in differentiated cell lines (MKN7 and MKN74) from that in undifferentiated ones (KATO III and FU97). Our data and these reports support once more the importance of selecting an appropriate cell line to study the response to drugs or nutritional factors. In the present study, the human colon cancer cells were chosen with distinct degree of differentiation according to their grade of infiltration or metastasis, in an effort to represent the diversity of cellular changes occurring in both precancerous lesions and manifest tumors. The validity of colorectal cancer cell lines as tools to investigate colorectal cancer biology and the response to different antiproliferative compounds is now widely accepted and it has been established also at a genomic level that human colorectal cancer cells are representative of the main subtypes of primary tumors (40). Besides, when applied in an orthotopic model of tumors, twelve well-described colorectal cancer cell lines including those of interest in the present study, resulted in variable disease progression that seemingly reflects clinically relevant heterogeneity (41). Overall, the differences in the proliferative response of cultured cells to L.GG and VK1 co-administration appeared to be related to the specific cell features, being more evident in the most differentiated cell lines (Caco-2 cells followed by HT-29 ones, originating from well differentiated and moderately well differentiated adenocarcinoma, respectively) than in SW480 cells.

To the best of our knowledge, this is the first study aimed at evaluating in colon cancer cell lines, the anticancer potential exerted by L.GG co-administered with the natural compound VK1. Few studies, if any, are available on probiotics and VK1. Investigations performed in the oral cavity $(42,25)$ showed the beneficial effects of several Bifidobacterium strains in contrasting the growth of a pathogen bacteria (namely Porphyromonas gingivalis) by reducing the concentration of VK acting as its growth factor. Therefore, in addition to the well known effects on clotting cascade as well as the newly described promising anticancer activities, a growth promoting activity for VK1 has to be hypothesized. When administered to L.GG, it stimulated the growth of probiotic already after $4 \mathrm{~h}$, reaching the statistical significance at $18 \mathrm{~h}$ of incubation. In this perspective, it is plausible that VK1 could function as a growth factor also for L.GG, enhancing mostly the probiotic antiproliferative effect.

As concerns the L.GG concentration used in this study, $10^{8} \mathrm{CFU} / \mathrm{ml}$ was lower in comparison to the daily intake (3x $\left.10^{8} \mathrm{CFU} / \mathrm{ml}\right)$ suggested in in vivo studies (43), but sufficient for the adhesion of this strain to the colon cancer cells (19). Besides, VK1 concentrations ranging from 10 to $200 \mu \mathrm{M}$ can be considered pharmacological, since normal serum levels of VK1 were found to be $\sim 0.61 \mathrm{ng} / \mathrm{ml}$. Yet, VK1 appears to be without toxicity and studies performed in humans established that mega doses of VK1 (up to $1,000 \mathrm{mg}$ orally daily) were used without side-effects in patients with HCC (44).

From a therapeutic point of view, the observed enhanced antiproliferative efficacy exerted by the co-administration of L.GG and VK1 could represent a suitable option in a personal- ized functional food strategy for chemoprevention and cancer growth inhibition. Additional studies in humans are required and surely practicable, considering that these substances are safe and non-toxic. In this way, it will be possible to focus better on the appropriate doses needed to reproduce in vivo the positive anti-cancer effects suggested by experimental models.

\section{References}

1. Lepage C, Hamza S and Faivre J: Epidemiology and screening of colon cancer. Rev Prat 60: 1062-1067, 2010 (In French).

2. Johnson JJ and Mukhtar H: Curcumin for chemoprevention of colon cancer. Cancer Lett 255: 170-181, 2007.

3. Bazuro GE, Torino F, Gasparini G and Capurso L: Chemoprevention in gastrointestinal adenocarcinoma: For few but not for all? Minerva Gastroenterol Dietol 54: 429-444, 2008.

4. Linsalata $\mathrm{M}$ and Russo F: Nutritional factors and polyamine metabolism in colorectal cancer. Nutrition 24: 382-389, 2008

5. Shearer MJ and Newman P: Metabolism and cell biology of vitamin K. Thromb Haemost 100: 530-547, 2008.

6. Lamson DW and Plaza SM: The anticancer effects of vitamin K. Altern Med Rev 8: 303-318, 2003.

7. Mizuta T and Ozaki I: Hepatocellular carcinoma and vitamin K. Vitam Horm 78: 435-442, 2008.

8. Ozaki I, Zhang H, Mizuta T, Ide Y, Eguchi Y, Yasutake T, Sakamaki T, Pestell RG and Yamamoto K: Menatetrenone, a vitamin $\mathrm{K} 2$ analogue, inhibits hepatocellular carcinoma cell growth by suppressing cyclin D1 expression through inhibition of nuclear factor kappaB activation. Clin Cancer Res 13: 2236-2245, 2007.

9. Du W, Zhou JR, Wang DL, Gong K and Zhang QJ: Vitamin K1 enhances sorafenib-induced growth inhibition and apoptosis of human malignant glioma cells by blocking the Raf/MEK/ERK pathway. World J Surg Oncol 10: 60, 2012.

10. Orlando A, Linsalata M, Tutino V, D'Attoma B, Notarnicola M and Russo F: Vitamin K1 exerts antiproliferative effects and induces apoptosis in three differently graded human colon cancer cell lines. BioMed Res Int 2015: 296721, 2015.

11. Linsalata M, Orlando A, Tutino V, Notarnicola M, D'Attoma B and Russo F: Inhibitory effect of vitamin $\mathrm{K} 1$ on growth and polyamine biosynthesis of human gastric and colon carcinoma cell lines. Int J Oncol 47: 773-781, 2015

12. Thomas T and Thomas TJ: Polyamine metabolism and cancer. J Cell Mol Med 7: 113-126, 2003.

13. Aureli P, Capurso L, Castellazzi AM, Clerici M, Giovannini M, Morelli L, Poli A, Pregliasco F, Salvini F and Zuccotti GV: Probiotics and health: an evidence-based review. Pharmacol Res 63: 366-376, 2011.

14. Kumar M, Kumar A, Nagpal R, Mohania D, Behare P, Verma V, Kumar P, Poddar D, Aggarwal PK, Henry CJ, et al: Cancerpreventing attributes of probiotics: An update. Int J Food Sci Nutr 61: 473-496, 2010.

15. Linsalata M, Russo F, Berloco P, Valentini AM, Caruso ML, De Simone C, Barone M, Polimeno L and Di Leo A: Effects of probiotic bacteria (VSL\#3) on the polyamine biosynthesis and cell proliferation of normal colonic mucosa of rats. In Vivo 19: 989-995, 2005.

16. Uccello M, Malaguarnera G,Basile F,D'agata V,Malaguarnera M, Bertino G, Vacante M, Drago F and Biondi A: Potential role of probiotics on colorectal cancer prevention. BMC Surg 12 (Suppl 1): S35, 2012.

17. You HJ, Oh DK and Ji GE: Anticancerogenic effect of a novel chiroinositol-containing polysaccharide from Bifidobacterium bifidum BGN4. FEMS Microbiol Lett 240: 131-136, 2004.

18. Orlando A, Messa C, Linsalata M, Cavallini A and Russo F: Effects of Lactobacillus rhamnosus GG on proliferation and polyamine metabolism in HGC-27 human gastric and DLD-1 colonic cancer cell lines. Immunopharmacol Immunotoxicol 31: 108-116, 2009.

19. Orlando A, Refolo MG, Messa C, Amati L, Lavermicocca P, Guerra V and Russo F: Antiproliferative and proapoptotic effects of viable or heat-killed Lactobacillus paracase $i$ IMPC2.1 and Lactobacillus rhamnosus GG in HGC-27 gastric and DLD-1 colon cell lines. Nutr Cancer 64: 1103-1111, 2012.

20. Roberfroid M: Prebiotics: The concept revisited. J Nutr 137 (Suppl 2): 830S-837S, 2007. 
21. Gibson GR and Roberfroid MB: Dietary modulation of the human colonic microbiota: Introducing the concept of prebiotics. J Nutr 125: 1401-1412, 1995.

22. Bomba A, Nemcová R, Gancarcíková S, Herich R, Guba P and Mudronová D: Improvement of the probiotic effect of micro-organisms by their combination with maltodextrins, fructo-oligosaccharides and polyunsaturated fatty acids. Br J Nutr 88 (Suppl 1): S95-S99, 2002.

23. Wyss C: Growth of Porphyromonas gingivalis, Treponema denticola, T. pectinovorum, T. socranskii, and T. vincentii in a chemically defined medium. J Clin Microbiol 30: 2225-2229, 1992.

24. Bowler PG, Duerden BI and Armstrong DG: Wound microbiology and associated approaches to wound management. Clin Microbiol Rev 14: 244-269, 2001.

25. Hojo K, Nagaoka S, Murata S, Taketomo N, Ohshima T and Maeda N: Reduction of vitamin K concentration by salivary Bifidobacterium strains and their possible nutritional competition with Porphyromonas gingivalis. J Appl Microbiol 103: 1969-1974, 2007.

26. Brunner H, Hausmann F, Krieg RC, Endlicher E, Schölmerich J, Knuechel R and Messmann H: The effects of 5-aminolevulinic acid esters on protoporphyrin IX production in human adenocarcinoma cell lines. Photochem Photobiol 74: 721-725, 2001

27. Linsalata M, Notarnicola M, Tutino V, Bifulco M, Santoro A, Laezza C, Messa C, Orlando A and Caruso MG: Effects of anandamide on polyamine levels and cell growth in human colon cancer cells. Anticancer Res 30: 2583-2589, 2010.

28. Siegel RL, Miller KD and Jemal A: Cancer statistics, 2015. CA Cancer J Clin 65: 5-29, 2015.

29. Chan AT and Giovannucci EL: Primary prevention of colorectal cancer. Gastroenterology 138: 2029-2043.e2010, 2010.

30. Ligibel J: Lifestyle factors in cancer survivorship. J Clin Oncol 30: 3697-3704, 2012.

31. Reid G, Jass J, Sebulsky MT and McCormick JK: Potential uses of probiotics in clinical practice. Clin Microbiol Rev 16: 658-672, 2003.

32. Liong MT: Roles of probiotics and prebiotics in colon cancer prevention: Postulated mechanisms and in-vivo evidence. Int J Mol Sci 9: 854-863, 2008.

33. Lam EK, Tai EK, Koo MW, Wong HP, Wu WK, Yu L, So WH, Woo PC and Cho CH: Enhancement of gastric mucosal integrity by Lactobacillus rhamnosus GG. Life Sci 80: 2128-2136, 2007.

34. Drisko JA, Giles CK and Bischoff BJ: Probiotics in health maintenance and disease prevention. Altern Med Rev 8: 143-155, 2003
35. Yan F and Polk DB: Probiotic bacterium prevents cytokineinduced apoptosis in intestinal epithelial cells. J Biol Chem 277: 50959-50965, 2002

36. Linsalata M, Cavallini A, Messa C, Orlando A, Refolo MG and Russo F: Lactobacillus rhamnosus GG influences polyamine metabolism in HGC-27 gastric cancer cell line: A strategy toward nutritional approach to chemoprevention of gastric cance. Curr Pharm Des 16: 847-853, 2010.

37. Showalter SL, Wang Z, Costantino CL, Witkiewicz AK, Yeo CJ, Brody JR and Carr BI: Naturally occurring K vitamins inhibit pancreatic cancer cell survival through a caspase-dependent pathway. J Gastroenterol Hepatol 25: 738-744, 2010.

38. Moreno-Vilet L, Garcia-Hernandez MH, Delgado-Portales RE, Corral-Fernandez NE, Cortez-Espinosa N, Ruiz-Cabrera MA and Portales-Perez DP: In vitro assessment of agave fructans (Agave salmiana) as prebiotics and immune system activators. Int J Biol Macromol 63: 181-187, 2014.

39. Tokita H, Tsuchida A, Miyazawa K, Ohyashiki K, Katayanagi S, Sudo H, Enomoto M, Takagi Y and Aoki T: Vitamin K2-induced antitumor effects via cell-cycle arrest and apoptosis in gastric cancer cell lines. Int J Mol Med 17: 235-243, 2006.

40. Mouradov D, Sloggett C, Jorissen RN, Love CG, Li S, Burgess AW, Arango D, Strausberg RL, Buchanan D, Wormald S, et al: Colorectal cancer cell lines are representative models of the main molecular subtypes of primary cancer. Cancer Res 74: 3238-3247, 2014.

41. Flatmark K, Maelandsmo GM, Martinsen M, Rasmussen $\mathrm{H}$ and Fodstad $\varnothing$ : Twelve colorectal cancer cell lines exhibit highly variable growth and metastatic capacities in an orthotopic model in nude mice. Eur J Cancer 40: 1593-1598, 2004

42. Glick MC, Zilliken F and Gyorgy P: Supplementary growth promoting effect of 2-methyl-1,4-naphthoquinone of Lactobacillus bifidus var. pennsylvanicus. J Bacteriol 77: 230-236, 1959

43. Alander M, Satokari R, Korpela R, Saxelin M, VilpponenSalmela T, Mattila-Sandholm T and von Wright A: Persistence of colonization of human colonic mucosa by a probiotic strain, Lactobacillus rhamnosus GG, after oral consumption. Appl Environ Microbiol 65: 351-354, 1999.

44. Wei G, Wang M, Hyslop T, Wang Z and Carr BI: Vitamin K enhancement of sorafenib-mediated HCC cell growth inhibition in vitro and in vivo. Int J Cancer 127: 2949-2958, 2010. 